\title{
Survey of ERETIC2 NMR for quantification
}

\author{
Ran Seon Hong ${ }^{1 \dagger}$, Kyung Hwa Hwang ${ }^{2}$, Suncheun Kim ${ }^{1,3}$, Hwang Eui Cho ${ }^{1}$, Hun Joo Lee ${ }^{4}$, Jin \\ Tae Hong ${ }^{1}$, Dong Cheul Moon ${ }^{1 *}$
}

\author{
${ }^{1}$ College of Pharmacy, Chungbuk National University, Cheongju 361-763, Korea \\ ${ }^{2}$ Analytical Research Center, Korea Institute of Toxicology, Daejeon 305-343, Republic of Korea \\ ${ }^{3}$ National Forensic Service, Daejeon 305-348, Korea \\ ${ }^{4}$ Korea University, Department of Convergence IT, Seoul 136-701, Korea
}

Received Nov 10, 2013; Revised Dec 09, 2013; Accepted Dec 18, 2013

\begin{abstract}
The ERETIC (Electronic REference To access In vivo Concentrations) 2 method is a new qNMR experimental technique to measure analytes based on the signal of the reference compound without additional hardware equipment. In this study, ERETIC2 method was validated, and we sought to identify whether it would be possible to apply this method to a specific compound analysis of metabolites in plant. The $90^{\circ}$ pulse value (P1) and spin-lattice relaxation time $\left(T_{1}\right)$ of each compound were measured for ERETIC2. The $9^{1} \mathrm{H}$ of 3-(trimethylsilyl) propionic-2,2,3,3- $\mathrm{d}_{4}$ acid (TSP) was used as a reference peak for ERETIC 2, and then, a suitable solvent and pulse sequence for each compound were selected. Under the NOESY-presat sequence, the relative accuracy error for quantitative analyses of primary metabolites was within the range of $5 \%$, with the exception of glucose, which showed $\geq 55 \%$ error due to saturation. It showed excellent results for the quantification of glucose by using a $30^{\circ}$ pulse sequence, which did not suppress the water peak. In addition, the quantitative accuracy for secondary metabolites was extremely accurate, with an error $\leq 5 \%$ when considering the purity of the standard sample. The ERETIC2 method showed outstanding linearity, precision, and accuracy.
\end{abstract}

Keywords qNMR, ERETIC, quantification

\section{Introduction}

Nuclear magnetic resonance (NMR) is a qualitative and quantitative analytical technique. It is the only physical method used routinely that can provide quantitative valuable information at the molecular level. Therefore NMR has found various applications in other fields than chemistry, such as metabolomics methodology ${ }^{1}$, biomedical researches, and in vitro quantitative analysis of complex matrices ${ }^{2-4}$. The area of a ${ }^{1} \mathrm{H}$ NMR signal is directly proportional to the number of corresponding nuclei. And it does not depend on the structure of molecules ${ }^{5}$. Thus, the history of quantitative NMR (qNMR) was quite long. The first quantitative measurement was reported about phenacetine, aspirin, and caffeine in $1963^{6-7}$. As per fast development of NMR spectrometer and pulse sequence technique, qNMR study has been progressing for the last 40 years. Moreover the ${ }^{1} \mathrm{H}$ qNMR has been proven to be highly suitable for the simultaneous selective recognition and quantitative determination of metabolites in complex biological matrices $^{8}$. The qNMR has found advantages like, the possibility of determine structures at a molecular level, no need for intensity calibrations in case of determination of ratios, relatively short measuring times, its non-destructive character, easy sample preparation and handling, and the possibility of a

* Address correspondence to: Dong Cheul Moon, College of Pharmacy, Chungbuk National University, Cheongju 361-763, Korea, Tel: 82-43-261-2819; Fax: 82-43-268-2723; E-mail: dcmoon@cbnu.ac.kr 
simultaneous determination of more than one analyte in a mixture ${ }^{9}$. Thus, qNMR methodology study has become an emerging area recently 9 . Previously qNMR was reported on the use of an internal standard method in pharmaceutical analysis. However, the conventional method using ${ }^{1} \mathrm{H}$ NMR assay with internal standard (IS) has a problem with finding a material which does not allow the chemical shift of analyte. Compared with basic concept of qNMR, the ERETIC technique using electronical signal is useful for quantitative analyses of biological samples and metabolomics due to its capability of direct measurements without IS and analyte standard materials ${ }^{3,11}$. Furthermore, very good quantitative accuracy can be achieved in a short time by using a standard material. However, although ERETIC has the merit, it was not easy to approach to this method in the laboratory because this requires additional installation of hardware. On the other hand, with development of software for equipment operation, ERETIC2 experiment without additional hardware installation is now possible. The module ERETIC2 (TopSpin, ver. 3.0, Bruker Biospin) is based on PULCON (pulse length based concentration determination $)^{12}$, an internal standard method which correlates the absolute intensities of two different spectra. The ERETIC2 only needs a 1D spectrum measured on a sample of known concentration, under "quantitative" condition: a tuned and matched probe exactly, a calibrated $90^{\circ}$ pulse, a relaxation delay time to at least $5^{*} T_{1}$, an acquisition time longer than $T_{2}$, and sufficient signal to noise. The correlation between this spectrum and those of unknown concentrations can also be depicted by a digitally synthetized signal, whose integral value stands for one nucleus at the concentration of the reference sample. But, sufficient research supporting its use for the quantification analysis has not been reported to date.

The purpose of this study is to inspect the quantitative accuracy of various metabolites structures by using the new module ERETIC2 as quantitative software.

\section{Experimental Methods}

Sample preparation- The samples were selected from the common metabolites found in plants by ${ }^{1} \mathrm{H}$ NMR. Primary metabolites were divided into the amino acids, sugars and organic acid group and then $2 \sim 3$ compounds were selected from each group (Figure 1). And it is attempted to select structurally different substances of secondary metabolites. Reference materials were dissolved in deuterium solvents which can dissolve each compound (TSP, amino acid, saccharide, organic compounds in D2O, and remainder in MeOD). The stock solutions of 17 compounds were prepared. Working solutions were prepared through serial dilutions $(0.5,1.0,2.0,10.0$, and $20.0 \mathrm{mM}$ ) of the standard stock solutions with NMR solvent. All of the solutions were stored at $4{ }^{\circ} \mathrm{C}$ prior to analysis. The seventeen reference standards, whose abbreviations and certified purities from the manufacturer given in each parentheses, were as follows; 3-(trimethylsilyl) propionic-2,2,3,3- $\mathrm{d}_{4}$ acid (TSP) sodium salt $(98 \%$ atom \%D), L-alanine ( $\geq$ 99.5\%), L-proline ( $\geq 99.5 \%$ ), Glycine $(\geq 98.5 \%$ ), D-glucose ( $\geq 99.5 \%$ ), sucrose $(\geq 99.5 \%)$, succinic acid ( $\geq 99 \%$ ), fumaric acid ( $\geq 99 \%$ ), malic acid $(\geq$ $99 \%$ ), salicylic acid ( $\geq 99 \%)$, betaine $(\geq 99 \%)$, taurine $(\geq 99 \%), \quad$ ibuprofen $(\geq 99 \%), \quad 4,4^{\prime}$ ethylidenebisphenol $(\geq 99 \%)$, naringin ( $\geq 95 \%$, from citrus fruit), berberine chloride hydrate $(\geq 90 \%)$, procaine hydrochloride $(\geq 97 \%)$ were purchased from Sigma (St. Louis, MO, U.S.A.). $\mathrm{D}_{2} \mathrm{O}, \mathrm{MeOD}$ and DMSO were purchased from EURISO-TOP (Saint-Aubin Cedex, France). All chemicals were of analytical grade and were used without further purification.

NMR experiments- NMR spectroscopy detection was performed on Bruker AVANCE III 400 equipped with a gradient broad band BBFO probe. The ERETIC2 method has been modified to provide a very simple procedure with no change in the spectrometer wiring. The first point was fulfilled by injecting the reference signal on the ${ }^{13} \mathrm{C}$ channel of the probe, without change any connection. To fit the exact frequency the probehead was tuned and 
matched automatically as command "atma exact". The $90^{\circ}$ pulse with as command "pulsecal" without option for proton was calibrated. The temperature was controlled at $298 \mathrm{~K}$. Spectra were the result of a line broadening of $0.3 \mathrm{~Hz}$. The spectra were subsequently manually phased, and the baseline was corrected by fitting with a $1^{\text {st }}$ polynomial curve. All the experimental conditions and parameters for<smiles>[2H]C([2H])(C(=O)O)C([2H])([2H])[Si](C)(C)C</smiles>

TSP (IS)

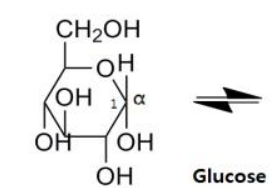<smiles>COc1ccc2cc3[n+](cc2c1OC)CCc1cc2c(cc1-3)OCO2</smiles><smiles>NCCS(=O)(=O)O</smiles><smiles>C[C](N)C(=O)O</smiles>

Alanine<smiles>O=C(O)C1CCCN1</smiles>

Proline

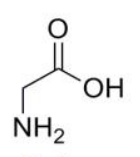

Glycine

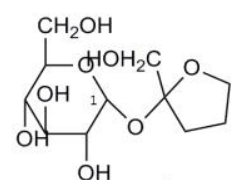

$\mathrm{OH}$<smiles>O=C(O)CCCC(=O)O</smiles>

$\mathrm{OH}$<smiles>O=C(O)/C=C/C(=O)O</smiles><smiles>O=C(O)C[C@@H](O)C(=O)O</smiles><smiles>O=C(O)c1ccccc1O</smiles>
Salicylic acid<smiles>C[N+](C)(C)CC(=O)O</smiles><smiles>CCN(CC)CCOC(=O)c1ccc(N)cc1</smiles>

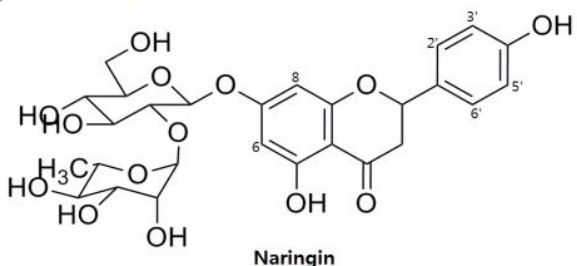

Figure 1. Structure of 17 compounds

summation of 32 transients, with data collected into $64 \mathrm{~K}$ data points using a spectral width of $4801 \mathrm{~Hz}$. The NMR spectra for each sample were acquired using two methods; $30^{\circ}$ pulse sequence with a relaxation delay of $1.0 \mathrm{~s}$ and NOESY-presat $20.0 \mathrm{~s}$ or $30.0 \mathrm{~s}$. sec. The $T_{1}$ values were acquired by using an inversion recovery sequence with 10 inversion time values between the range of $10 \mathrm{~ms}-15 \mathrm{~s}(0.01,0.05$, $0.1,0.25,0.5,1,2,4,8,15 \mathrm{~s})$. Subsequently, data was computed by using the $T_{1}$ calculation software of the spectrometer. ERETIC reference peak was determined based on $9^{1} \mathrm{H}$ attached to TSP and integral value for ${ }^{1} \mathrm{H}$ was indicated at $\delta-0.5 \mathrm{ppm}$ accordingly. The concentration of reference sample was $2 \mathrm{mM}$ and ERETIC signal was situated at $\delta-0.5$

NMR data processing- After acquisition, spectrum was multiplied by an exponential window function to calibration and quantification analysis were equally set. Each selected signal was integrated three times and the results were averaged in order to minimize errors from manual integration. The determination of concentrations by NMR is need that the integration in the spectrum of a reference sample is correlated with

$$
C_{U N K}=k C_{R E F} \frac{A_{U N K} T_{U N K} \theta_{90}^{U N K} n_{R E F}}{A_{R E F} T_{R E F} \theta_{90}^{R E F} n_{U N K}}
$$

signal strength in the analyte of interest with unknown concentration ${ }^{12}$. The unknown concentrations can be obtained using the following equation:

where the UNK and REF indices stand for unknown and reference respectively, $\mathrm{C}$ is the concentration, $\mathrm{T}$ is the temperature, $\theta_{90}$ is the $90^{\circ}$ pulse length, $\mathrm{n}$ is the number of transients used for the experiments, 
and $\mathrm{k}$ is a correction factor taking into account the use of different receiver gains for measurement of the reference and of the unknown samples (Figure 2).

Partial method validation- The ERETIC2 method was validated in terms of precision, accuracy, and linearity. The quality control (QC) samples were measured in three replicate for accuracy test. The precision of the ERETIC2 method was evaluated by the inter-day variability test and described as relative standard deviation (RSD). The accuracy of measurement is the degree of agreement between the measured concentration and its true value:

$\delta=\left(\frac{\left|C_{\text {measured }}-C_{\text {true }}\right|}{C_{\text {true }}}\right) \times 100 \%$

where $C_{\text {measured }}$ and $C_{\text {true }}$ are the measured and true concentration respectively.

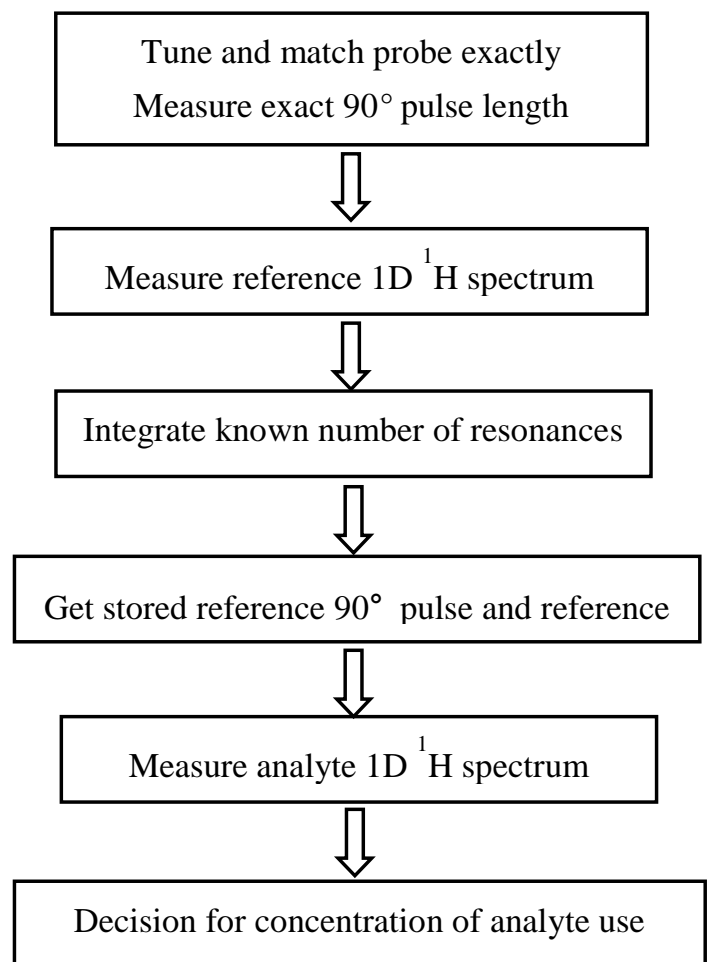

Figure 2. Flowchart of concentration measurement using ERETIC2 NMR.

\section{Results}

The chemical shifts, $90^{\circ}$ pulse length, and $T_{1}$ values of 16 metabolites are presented in table 1 . In this research of 17 compounds, minimum $T_{1}$ values for ${ }^{1} \mathrm{H}$ was 0.25 and most of them are 3 6 s. Therefore relaxation delay time was set at $20 \mathrm{~s}$ or $30 \mathrm{~s}$ according to their longest $T_{1}$ value. The results of the precision and accuracy of amino acids are presented in table 2. The precision was from 0.24 to $4.31 \%$ with the accuracy ranging from 0.58 to $3.77 \%$. These values within the acceptable range show that the method is considered precise and accurate enough for detecting and simultaneously quantitative evaluating of amino acid compounds. Glucose is much likely to exist in the form of hemiacetal. There are the two anomers of glucose, the $\alpha$ - and $\beta$-D-glucopyranoses in aqueous solutions with a small amount of the "open-chain" structure ${ }^{14}$. Two doublet ${ }^{1} \mathrm{H}$ NMR spectra appeared at $\delta 5.11$ and $4.52 \mathrm{ppm}$. The quantification values were defined by adding up two peaks. However, as for Glucose, more than $55 \%$ of errors in fixed quantity value were found during NOESY-presat experiment. It appears that a part of peaks were suppressed together with water peak, as these peaks are very close to water peak. To solve this problem, it was conducted second experiment without water suppression and gained a result of within $5 \%$ error range except for $0.5 \mathrm{mM}$. Therefore, it is shown that NOESY-presat experiment is not suitable for Glucose quantitative experiment and removing moisture from sample is very important. Sucrose shows relative accuracy error within 3\% except for $0.5 \mathrm{mM}$ when conducting general $30^{\circ}$ pulse sequence experiment (D1=20 s). As for $0.5 \mathrm{mM}$, it proves that relaxation was not sufficient because concentration was low and $T_{1}$ rapidly became longer. Linearity of measured concentration shows very excellent results. Organic acid related substances show a high relative accuracy error within $4.2 \%$. Malic acid is made by all living organisms and has two stereoisomeric forms (L- and D-enantiomers), though only the L-isomer exists naturally. There are numerous individual studies where only single type of applications was reported. Taurine and betaine 
show high accuracy error within $1.62 \%$. Linearity of measured concentration shows taurine and betaine, which are very excellent results. When D1 is set at 20 $\mathrm{s}$, aromatic compounds show large errors, whereas when D1 is set at $30 \mathrm{~s}$, they show acceptable errors, which were considered due to not only their long $T_{1}$ relaxation time but also their aromaticity. Despite standard material, the purity of naringin $(\geq 95 \%$, from Citrus fruit), berberine ( $\geq 90 \%$ ), and procaine ( $\geq 97 \%$ ) was low. When considering the purity, they also show good accuracy (Table 3). An example of signals due to impurities was shown in Figure 3. Looking to expand the signal, the impurity peaks were seen. And linearity of the measured concentration in each compound was very excellent (Table 3). In case of protons splitting by multiplet, their accuracy is not good due to relatively low signal strength for example $\mathrm{H}(11)$ of ibuprofen with a septet. These results mean that it is important to ensure sufficient D1 relaxation delay time considered $T_{1}$ and structural characteristics for accuracy and to select less splitting proton in analyte for sensitivity of quantitative analyses. An error between the ${ }^{1} \mathrm{H}$ within compound is considered due to the ${ }^{13} \mathrm{C}$ satellite peaks, uneven baseline, mixed impurity, and different $\mathrm{S} / \mathrm{N}$. And the $90^{\circ}$ pulse values between reference sample and 16 compounds differed as $8.07 \mu$ s to $9.89 \mu$ s, but did not greatly affect the accuracy. Consequently, it is approved that it is possible to quantify various metabolites using any reference standard showing appropriate proton signal in ERETIC2.

\section{Discussion}

In this work we have shown that analyte concentration can be reliably measured by NMR spectroscopy without adding any reference compound. An alternative quantification method called ERETIC2 ${ }^{1} \mathrm{H}$ NMR has been validated to quantify the absolute concentration of the 16 metabolites. This is the first time the ERETIC2 method has been applied to quantify various metabolites in plant, and the results obtained in our present study illustrated the effectiveness of this technique for quantification analysis. Only one reference spectrum is required per probe, and it can be used for all metabolites. With the long-term stability of modern NMR spectrometers, the reference sample need not be measured with every measurement of various analytes. The proposed ERETIC2 method was demonstrated to be simple, rapid, and accurate over the reported conventional quantitative methods. The ERETIC2 method does not require quantitative reference substances for calibration curves preparation. It provides sufficient precision, accuracy, and reproducibility. Therefore, the ERETIC2 NMR is considered helpful for absolute quantification and purity determination of organic compounds.

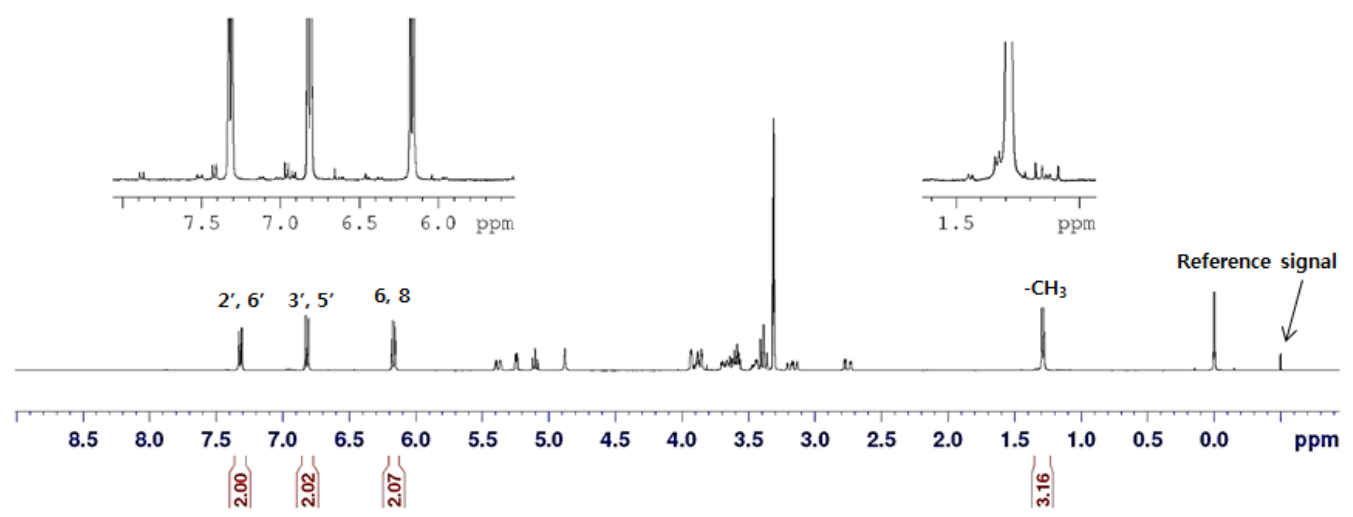

Figure 3. ${ }^{1} \mathrm{H}$ spectrum of naringin. The reference signal was situated at $\delta-0.5$. 
Table 1. Chemical shift, $90^{\circ}$ pulse length (P1), and $T_{1}$ values of protons in each compound at $2 \mathrm{mM}$

\begin{tabular}{|c|c|c|c|c|c|c|c|}
\hline Compound & $\delta(\mathrm{ppm})$ & $\begin{array}{c}\text { P1 } \\
(\mu \mathrm{sec})\end{array}$ & $\begin{array}{l}T_{1} \\
\text { (s) }\end{array}$ & Compound & $\delta(\mathrm{ppm})$ & $\begin{array}{c}\text { P1 } \\
(\mu \mathrm{sec})\end{array}$ & $\begin{array}{l}T_{1} \\
\text { (s) }\end{array}$ \\
\hline TSP & $0.0(\mathrm{~s}, 9 \mathrm{H})$ & $\begin{array}{l}9.28 \\
\left(\mathrm{D}_{2} \mathrm{O}\right)\end{array}$ & 3.66 & \multirow[t]{6}{*}{ Ibuprofen } & $0.88(\mathrm{~d}, J=6.64 \mathrm{~Hz}, 6 \mathrm{H}, \mathrm{H} 12,13)$ & \multirow[t]{6}{*}{9.24} & 1.43 \\
\hline Alanine & $1.49(\mathrm{~d}, J=7.2 \mathrm{~Hz}, 3 \mathrm{H})$ & 9.3 & 1.87 & & $\begin{array}{l}1.43(\mathrm{~d}, J=7.16 \mathrm{~Hz}, 3 \mathrm{H}, \mathrm{H} 8) \\
1.83(\mathrm{~m}, 1 \mathrm{H}, \mathrm{H} 11)\end{array}$ & & $\begin{array}{r}1.02 \\
1.7\end{array}$ \\
\hline \multirow[t]{2}{*}{ Proline } & $2.25(\mathrm{~m}, 1 \mathrm{H})$ & \multirow[t]{2}{*}{9.28} & 3.15 & & $2.44(\mathrm{~d}, J=7.20 \mathrm{~Hz}, 2 \mathrm{H}, \mathrm{H} 10)$ & & 1.45 \\
\hline & $4.12(\mathrm{dd}, 8.86,6.30 \mathrm{~Hz}, 2 \mathrm{H}-3)$ & & 4.99 & & $3.66(\mathrm{q}, J=7.14 \mathrm{~Hz}, 1 \mathrm{H}, \mathrm{H} 7)$ & & 2.69 \\
\hline Glycine & $3.55(\mathrm{~s}, 2 \mathrm{H})$ & 9.22 & 4.26 & & $7.08(\mathrm{~d}, J=8.05 \mathrm{~Hz}, 2 \mathrm{H}, \mathrm{H} 2,6)$ & & 2.59 \\
\hline \multirow[t]{2}{*}{ Glucose } & $5.11(\mathrm{~d}, J=3.8 \mathrm{~Hz}, 1 \mathrm{H}-\alpha)$ & 9.24 & 6.64 & & $7.20(\mathrm{~d}, J=8.23,2 \mathrm{H}, \mathrm{H} 3,5)$ & & 2.81 \\
\hline & $4.52(\mathrm{~d}, J=7.9 \mathrm{~Hz}, 1 \mathrm{H}-\beta)$ & 9.24 & 251 & \multirow[t]{8}{*}{ Berberine } & $4.09\left(\mathrm{~s}, 3 \mathrm{H}, \mathrm{OCH}_{3}-9\right)$ & 9.37 & 1.06 \\
\hline \multirow[t]{2}{*}{ Sucrose } & $5.31(\mathrm{~d}, J=3.9 \mathrm{~Hz}, 1 \mathrm{H}-\alpha)$ & \multirow[t]{2}{*}{9.25} & 2.84 & & $4.17\left(\mathrm{~s}, 3 \mathrm{H}, \mathrm{OCH}_{3}-10\right)$ & & 2.04 \\
\hline & $4.12(\mathrm{~d}, J=8.76 \mathrm{~Hz}, 1 \mathrm{H})$ & & 0.58 & & $6.09\left(\mathrm{~s}, 2 \mathrm{H}, \mathrm{OCH}_{2} \mathrm{O}\right)$ & & 4.28 \\
\hline Succinic acid & $2.66(\mathrm{~s}, 4 \mathrm{H})$ & 9.28 & 1.43 & & $7.60(\mathrm{~s}, 1 \mathrm{H}, \mathrm{H}-1)$ & & 3.5 \\
\hline Fumaric acid & $6.74(\mathrm{~s}, 2 \mathrm{H})$ & 9.34 & 6.39 & & $8.01(\mathrm{~d}, J=9.04 \mathrm{~Hz}, 1 \mathrm{H}, \mathrm{H}-12)$ & & 4.22 \\
\hline \multirow{2}{*}{ Malic acid } & $2.84(\mathrm{dd}, 16.46,7.20 \mathrm{~Hz}, 1 \mathrm{H})$ & \multirow[t]{2}{*}{9.28} & 1.23 & & $8.11(\mathrm{~d}, J=9.04 \mathrm{~Hz}, 1 \mathrm{H}, \mathrm{H}-11)$ & & 3.19 \\
\hline & $2.90(\mathrm{dd}, 16.21,4.52 \mathrm{~Hz}, 1 \mathrm{H})$ & & 1.11 & & $8.62(\mathrm{~s}, 1 \mathrm{H}, \mathrm{H}-13)$ & & 2.55 \\
\hline \multirow[t]{3}{*}{ Salicylic acid } & 7.0 (dd/ddd, $1 \mathrm{H}, \mathrm{H} 3,5)$ & 9.43 & 3.49 & & $9.71(\mathrm{~s}, 1 \mathrm{H}, \mathrm{H}-8)$ & & 3.24 \\
\hline & 7.6 (ddd, $1 \mathrm{H}, \mathrm{H} 4)$ & & 3.95 & \multirow{3}{*}{ Procaine } & $1.26(\mathrm{t}, J=7.24 \mathrm{~Hz}, 6 \mathrm{H})$ & 9.89 & 1.86 \\
\hline & $8.0(\mathrm{dd}, J=7.80,171 \mathrm{~Hz}, 1 \mathrm{H}, \mathrm{H} 6)$ & & 3.49 & & $6.61(\mathrm{~d}, J=8.80 \mathrm{~Hz}, 2 \mathrm{H}, \mathrm{H} 3,5)$ & & 3.5 \\
\hline \multirow{6}{*}{$\begin{array}{c}\text { Betaine } \\
\text { Taurine } \\
4,4^{\prime}- \\
\text { Ethylidenebisphenol }\end{array}$} & $3.2(\mathrm{~s}, 9 \mathrm{H})$ & 9.34 & 2.14 & & $7.75(\mathrm{~d}, J=8.80 \mathrm{~Hz}, 2 \mathrm{H}, \mathrm{H} 2,6)$ & & 3.16 \\
\hline & $3.15(\mathrm{t}, J=6.62 \mathrm{~Hz}, 2 \mathrm{H}-1)$ & 9.27 & 3.05 & \multirow[t]{5}{*}{ Naringin } & $1.41(\mathrm{~d}, J=6.20,3 \mathrm{H}, \mathrm{H}-\mathrm{R} 6)$ & 9.43 & 0.36 \\
\hline & $1.66(\mathrm{~d}, J=7.24 \mathrm{~Hz}, 3 \mathrm{H})$ & 9.36 & 9.13 & & $6.14(\mathrm{~d}, J=2.3 \mathrm{~Hz}, 1 \mathrm{H}, \mathrm{H} 8)$ & & 2.84 \\
\hline & $4.09(\mathrm{q}, J=7.29 \mathrm{~Hz}, 1 \mathrm{H}, \mathrm{Hc})$ & & 4.05 & & $6.16(\mathrm{~d}, J=2.3 \mathrm{~Hz}, 1 \mathrm{H}, \mathrm{H} 6)$ & & 2.84 \\
\hline & $6.78\left(\mathrm{~d}^{2} J=8.56 \mathrm{~Hz}, 2 \mathrm{H}, \mathrm{Hb}, \mathrm{b}^{\prime}\right)$ & & 4.88 & & $6.81\left(\mathrm{~d}, J=8.56 \mathrm{~Hz}, 2 \mathrm{H}, \mathrm{H}^{\prime}, 5^{\prime}\right)$ & & 2.94 \\
\hline & $7.15\left(\mathrm{~d}, J=8.48 \mathrm{~Hz}, 2 \mathrm{H}, \mathrm{Ha}, \mathrm{a}^{\prime}\right)$ & & 3.89 & & 7.31 (d, $\left.J=8.60 \mathrm{~Hz}, 2 \mathrm{H}, \mathrm{H}^{\prime}{ }^{\prime}, 6^{\prime}\right)$ & & 2.08 \\
\hline
\end{tabular}

Table 2. Precision and accuracy of the amino acid compounds

\begin{tabular}{|c|c|c|c|c|c|}
\hline Compound & $\begin{array}{c}\text { Nominal conc. } \\
(\mathrm{mM})\end{array}$ & $\begin{array}{c}\delta \\
(\mathrm{ppm})\end{array}$ & $\begin{array}{c}\text { Measured conc. } \\
(\mathrm{n}=3, \text { Mean } \pm \text { S.D., } \mathrm{mM})\end{array}$ & $\begin{array}{l}\text { RSD } \\
(\%)\end{array}$ & $\begin{array}{c}\text { Relative accuracy error } \\
(\%)\end{array}$ \\
\hline \multirow[t]{5}{*}{ Alanine } & 0.5 & 1.49 & $0.52 \pm 0.00$ & 0.67 & 3.77 \\
\hline & 1.0 & & $0.99 \pm 0.01$ & 0.76 & 1.14 \\
\hline & 2.0 & & $2.02 \pm 0.03$ & 1.49 & 0.90 \\
\hline & 10.0 & & $9.85 \pm 0.12$ & 1.12 & 1.51 \\
\hline & 20.0 & & $20.12 \pm 0.19$ & 0.96 & 0.64 \\
\hline \multirow[t]{5}{*}{ Proline } & 0.5 & 2.25 & $0.51 \pm 0.02$ & 4.31 & 0.37 \\
\hline & 1.0 & & $0.98 \pm 0.02$ & 1.65 & 1.55 \\
\hline & 2.0 & & $1.95 \pm 0.03$ & 1.45 & 2.30 \\
\hline & 10.0 & & $9.94 \pm 0.03$ & 0.35 & 0.58 \\
\hline & 20.0 & & $20.36 \pm 0.23$ & 1.14 & 1.85 \\
\hline \multirow[t]{5}{*}{ Glycine } & 0.5 & 3.55 & $0.49 \pm 0.01$ & 1.36 & 1.13 \\
\hline & 1.0 & & $0.98 \pm 0.01$ & 0.63 & 2.67 \\
\hline & 2.0 & & $1.98 \pm 0.01$ & 0.63 & 1.21 \\
\hline & 10.0 & & $9.76 \pm 0.02$ & 0.24 & 2.42 \\
\hline & 20.0 & & $19.73 \pm 0.05$ & 0.26 & 1.33 \\
\hline
\end{tabular}

Table 3. Partial validation results at full range of concentrations

\begin{tabular}{lccc}
\hline \multicolumn{1}{c}{ Compound } & Relative accuracy error (\%) & RSD (\%) & Linearity \\
\hline Alanine & $0.64 \sim 3.77$ & $0.67 \sim 1.49$ & $\mathrm{y}=1.0033 \mathrm{x}-0.0224, \mathrm{r}^{2}=0.9999$ \\
Proline & $0.37 \sim 2.30$ & $0.35 \sim 4.31$ & $\mathrm{y}=1.0174 \mathrm{x}-0.0684, \mathrm{r}^{2}=0.9999$ \\
Glycine & $1.13 \sim 2.67$ & $0.24 \sim 1.36$ & $\mathrm{y}=0.9854 \mathrm{x}-0.0139, \mathrm{r}^{2}=1$ \\
Sucrose & $0.21 \sim 3.97$ & $0.05 \sim 1.40$ & $\mathrm{y}=1.0010 \mathrm{x}-0.0605, \mathrm{r}^{2}=0.9999$ \\
Glucose & $2.00 \sim 10.00$ & $0.44 \sim 55.92$ & $\mathrm{y}=1.0339 \mathrm{x}-0.0188, \mathrm{r}^{2}=1$ \\
Succinic acid & $0.06 \sim 1.89$ & $0.00 \sim 0.76$ & $\mathrm{y}=0.9830 \mathrm{x}+0.0472, \mathrm{r}^{2}=0.9998$ \\
Fumaric acid & $0.03 \sim 0.58$ & $0.19 \sim 4.19$ & $\mathrm{y}=1.0006 \mathrm{x}+0.0261, \mathrm{r}^{2}=1$ \\
Malic acid & $0.06 \sim 3.85$ & $0.32 \sim 1.44$ & $\mathrm{y}=0.9850 \mathrm{x}+0.0182, \mathrm{r}^{2}=0.9999$ \\
Salicylic acid & $0.34 \sim 3.02$ & $0.08 \sim 2.87$ & $\mathrm{y}=1.0214 \mathrm{x}-0.0075, \mathrm{r}^{2}=1$ \\
Taurine & $0.26 \sim 0.98$ & $0.13 \sim 0.81$ & $\mathrm{y}=0.9966 \mathrm{x}+0.0051, \mathrm{r}^{2}=1$ \\
Betaine & $0.21 \sim 1.62$ & $0.04 \sim 0.50$ & $\mathrm{y}=0.9846 \mathrm{x}+0.0354, \mathrm{r}^{2}=1$ \\
Procaine $(\geq 97 \%$ purity) & $1.72 \sim 5.66$ & $0.11 \sim 1.59$ & $\mathrm{y}=1.0571 \mathrm{x}-0.0466, \mathrm{r}^{2}=0.9999$ \\
$4,4 '-$ Ethylidenebisphenol & $0.23 \sim 2.96$ & $0.20 \sim 0.76$ & $\mathrm{y}=0.9974 \mathrm{x}+0.0332, \mathrm{r}^{2}=1$ \\
buprofen & $0.31 \sim 2.91$ & $0.20 \sim 0.69$ & $\mathrm{y}=1.0030 \mathrm{x}+0.0138, \mathrm{r}^{2}=1$ \\
Berberine $(\geq 90 \%$ purity) & $4.51 \sim 9.68$ & $0.54 \sim 1.16$ & $\mathrm{y}=0.9639 \mathrm{x}-0.0238, \mathrm{r}^{2}=1$ \\
Naringin $(\geq 95 \%$ purity) & $6.28 \sim 11.74$ & $0.10 \sim 1.35$ & $\mathrm{y}=0.9218 \mathrm{x}-0.0098, \mathrm{r}^{2}=0.9999$ \\
& & & \\
\hline
\end{tabular}




\section{References}

1. V. Molinier, B. Fenet, J. Fitremann, A. Bouchu, Y. Queneau, Cabohydr.Res. 341, 1890. (2006).

2. S. Henzer-Schweizer, N. De Zanche, M. Pavan, U. Sturzenegger, A. Henning, NMR Biomed. $23,406$. (2010).

3. Ding P-L, Chen L-Q, Lu Y, Li Y-G, J. Pharm. Biome. Anal. 60, 44(2012.

4. M. C. Martinez-Bisbal, D. Monleon, O. Assemat, M. Piotto, J. Piquer, JL. Llacer, NMR Biomed. $22,199$. (2009).

5. M. Malet-Matrino, U. Holzbrabe, J. Pharm. Biome. Anal. 55, 1. (2011).

6. D. P. Hollis, Anal. Chem. 35, 938. (1963).

7. J. L. Jungnickel, J. W. Forbes, Anal. Chem. 35, 938. (1963).

8. F. Malz, H. Jancke, J. Pharm. Biome. Anal. 38, 813. (2005).

9. R.-S. Hong, H.-E. Cho, D.-C. Moon, J. Korean Magn. Reson. Soc. 17,40. (2013).

10. G. F. Pauli, B. U. Jaki, D. C. Lankin, J. Nat. Prod. 68, 133. (2005).

11. M. J. Albers, T. N. Butler, I. Rahwa, N. Bao, K. R. Keshari, M. G. Swanson, Magn. Reson. Med. $61,525$. (2009).

12. G. Wider, L. Dreier, J. Am. Chem. Soc. 128, 2571. (2006).

13. H. K. Kim, Y. H. Choi, R. Veroorte, Nat. Protoc. 128, 2571. (2006).

14. J. E. Gurst, J. Chem. Educ. 68, 1003. (1991).

15. Y. Jung, Y.-S. Jung, G.-S. Hwang, J. Korean Magn. Reson. Soc. 15, 90. (2011). 